\title{
Preparation and characterization of colloidal CdTe nanoparticles by laser ablation in liquids
}

\section{Amenah Ali Salman}

\author{
Department of Applied Sciences, University of Technology
}

E-mail: zamonalislman@yahoo.com

\section{Abstract}

Nanoparticles generation by laser ablation of a solid target in a liquid environment is an easy method. Cadmium Telluride (CdTe) colloidal nanoparticles have been synthesized by laser ablation $\mathrm{Nd}$ :YAG with wavelengths of $1064 \mathrm{~nm}$ and double frequency at 532 $\mathrm{nm}$, number of pulses 50 pulses, with pulse energy $=620 \mathrm{~mJ}, 700 \mathrm{~mJ}$ of a solid target CdTe is immersed in double distilled deionized water (DDIW) and in methanol liquid. Influences of the laser energy and different solutions on the formation and optical characterization of the CdTe nanoparticles have been studied using atomic force microscope (AFM) and the UV-Vis absorption. As a results, it leads to the absorbance in UV-Vis spectra of samples prepared in water at laser wavelength of $532 \mathrm{~nm}$ is lower than the absorbance of $1064 \mathrm{~nm}$ at same laser energy. AFM images show that CdTe NPs have spherical shape in nanometer size.
Key words

Semiconductors, laser ablation, CdTe NPs, $A F M$.

\section{Article info.}

Received: May. 2013

Accepted: Jan. 2014

Published: Apr. 2014

\section{تحضير ودراسة خواص الجسيمات النانوية للكادميوم تيليورايد بواسطة القشط بالليزر في السوائل المنة علي سلمان \\ قسم العلوم التطبيقية، الجامعة التكنولوجية}

ان تحضير الجسيمات النانوية بواسطة القنط بالليزر للهذف الصلب في الوسط السائل هي طريقة سهلة.

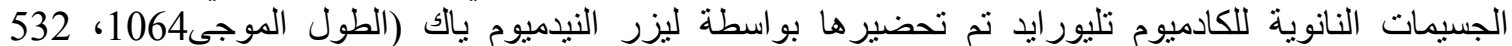

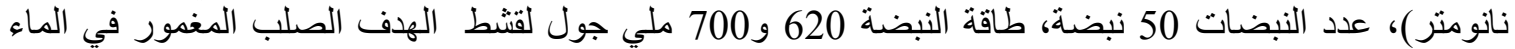

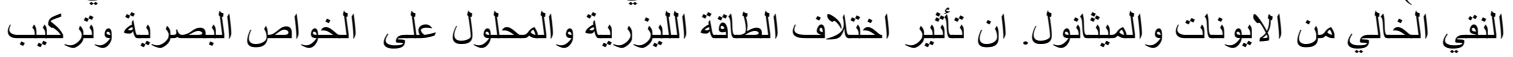

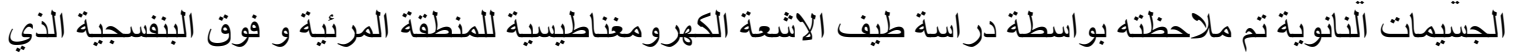

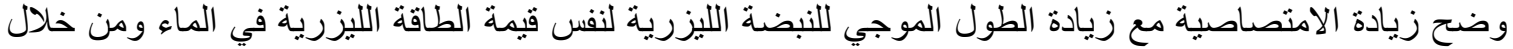
نتائج مجهر القوى الذرية وضح ان الجسيمات كروية وذات شكل منتظم اكثر في الميثانول مما في الماء وذات حجم في الماء

\section{Introduction}

Particles with dimensions in the nanometer range made out of II-VI semiconductors are important material for optoelectronic applications [1]. The vast majority of established high -yield method to synthesize nearly mono disperse II-VI semiconductors quantum

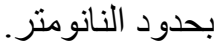

dot distributions is based on chemical approaches. The most widely used synthetic routes to synthesize $\mathrm{CdSe}$ and CdTe nanostructures use aqueous solutions facing various functional groups (e.g polar and unpolar thiols, amines and others) are employed to 
stabilize the particles[2]. Purely physical production methods which allow the synthesis of uncapped particles were limited to mechanical ball milling processes [3-5] and laser ablation in liquids, using laser ablation in liquids to generate noble metal nanoparticles in suspension is known since 1993[6-9] and was also applied to several non-metallic system $[9,10]$. Also semiconductors nanoparticles were fabricated by other methods, as deposits on different substrates by pulsed electron deposits technique [11], pulsed laser deposition [12] or pulsed laser ablation in argon gas atmosphere and methanol vapours [13] as well as by laser ablation in liquid environments(usually using long pulse laser sources at high flunces)[14].

The aim of the work are to prepare of CdTe NPs in different solutions by using laser ablation of a solid target through a liquid environment and shown the effect of the different laser wavelength and different solution on the morphology, particles size, absorption spectroscopy of obtained colloids and nanoparticles have been analyzed by UV-VIS spectrophotometer and atomic force microscope AFM.

\section{Experimental Work}

\section{Laser ablation}

The experimental set up for the ablation experiment is schematically shown in Fig.1. The laser light used for the ablation Nd:YAG laser $=1064,532 \mathrm{~nm}$, number of pulses $=50$ pulse, energy $=$ $620,700 \mathrm{~mJ}$. The pulses were focused onto a piece of bulk semiconductor which was held inside a quartz cell with $1 \mathrm{~cm}$ path length containing $1 \mathrm{ml}$ of solvent. The depth of the target immersed into the solution was kept at about $0.8 \mathrm{~cm}$. During the laser ablation of CdTe target, it was observed that the color of solution was changed and as is shown in the Fig. 2.

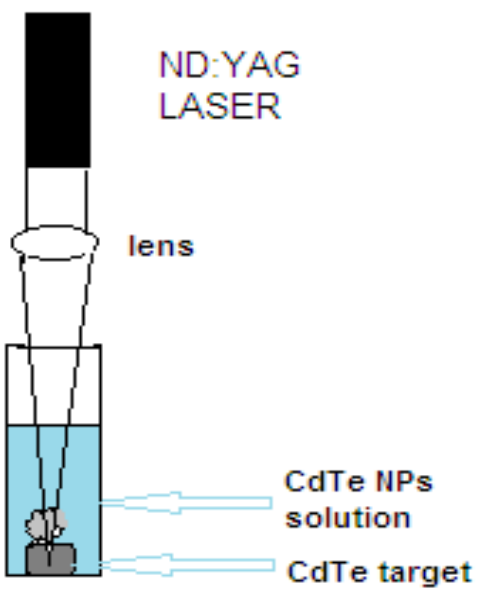

Fig.1: Experimental set-up for colloid preparation by laser ablation.

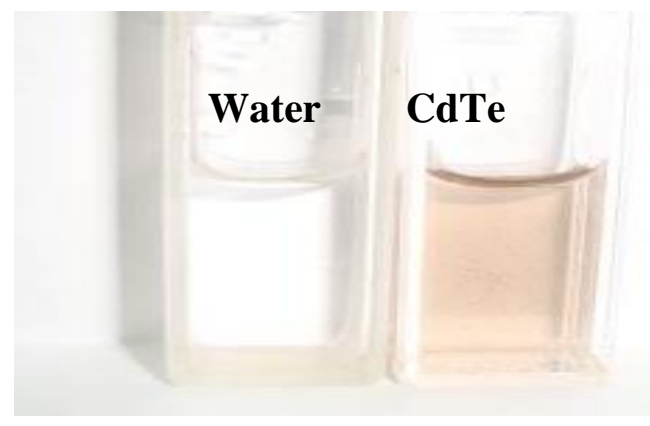

Fig.2: Photograph of colloidal CdTe nanoparticles.

\section{Absorption spectra}

Absorption spectra was measured by using UV-Vis spectrophotometer (PGinstrument) Before each ablation reference spectra of the pure solvent were measured in order to ensure that no traces of impurities remained in the ablation cell. The reference spectrum was also always subtracted from the absorption spectra of the colloidal suspensions.

\section{Solvent and Sample preparation}

The following solvents were used in the 
ablation experiment: double distilled water, methanol (with purity 99.9) these solvents were used without further purification bulk CdTe consisted of 50 $\% \mathrm{Cd}$ and $50 \% \mathrm{Te}[\mathrm{Eg}=1.499 \mathrm{eV}]$.

\section{Atomic Force Microscope (AFM)}

Samples of nanoparticles solution was dropped on substrates and then dried under lamp. Atomic force microscope (AFM) AA300 scanning probe microscope Angstrom Advanced Inc was used in this work.

\section{Results and Discussion}

\section{Laser ablation in DDIW}

During the laser ablation of CdTe target it was observed that the color of solution changed to grey. Fig.3 presents the absorption spectra of CdTe nanoparticles

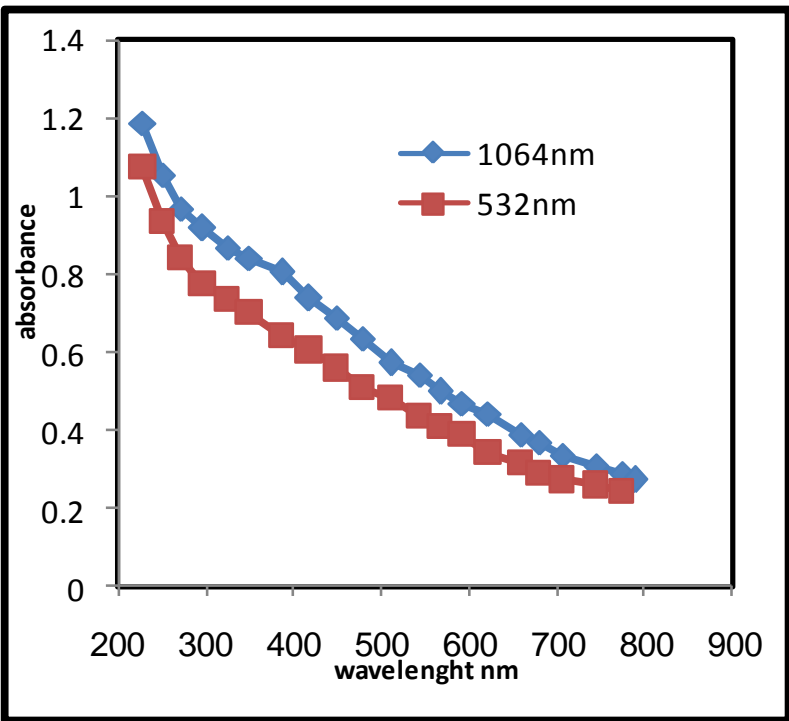

Fig.3: $\quad U V$-Vis absorption spectra of nanoparticles colloid fabricated at laser wavelenght of 532 and 1064nm in water. colloids after laser ablation in water at laser energy $700 \mathrm{~mJ}$ at wavelengths $1064 \mathrm{~nm}$ and $532 \mathrm{~nm}$, respectively. The absorption spectra increase continuously in the optical density from 800 to 200 and the UV absorbance increase when the laser wavelength increases at same energy. The absorption data are calculated using the Lambert-Beer law. The variation of $(\alpha h v)^{2}$ with photon energy (hv) is depicted in Fig.4a the optical band $\mathrm{Eg}$ of CdTe NPs is determined from extrapolating the liner part $(\alpha h v)^{2}$ hv plot on the $\mathrm{x}$-axis. The $\mathrm{NP}$ radius $\mathrm{R}$ (in the wavelength units) calculated according to the size quantization model for QDS that present in equation (1) [15-17].

$$
\begin{aligned}
\Delta \mathrm{E}= & \underset{\left(\pi^{2} \hbar^{2} / 2 \mathrm{~m}^{*} \mathrm{R}^{2}\right)-\left(1.8 \mathrm{e}^{2} / 4 \pi \epsilon \epsilon_{0} \mathrm{R}\right)}{\mathrm{E}} \mathrm{g}^{\text {bulk }}=
\end{aligned}
$$

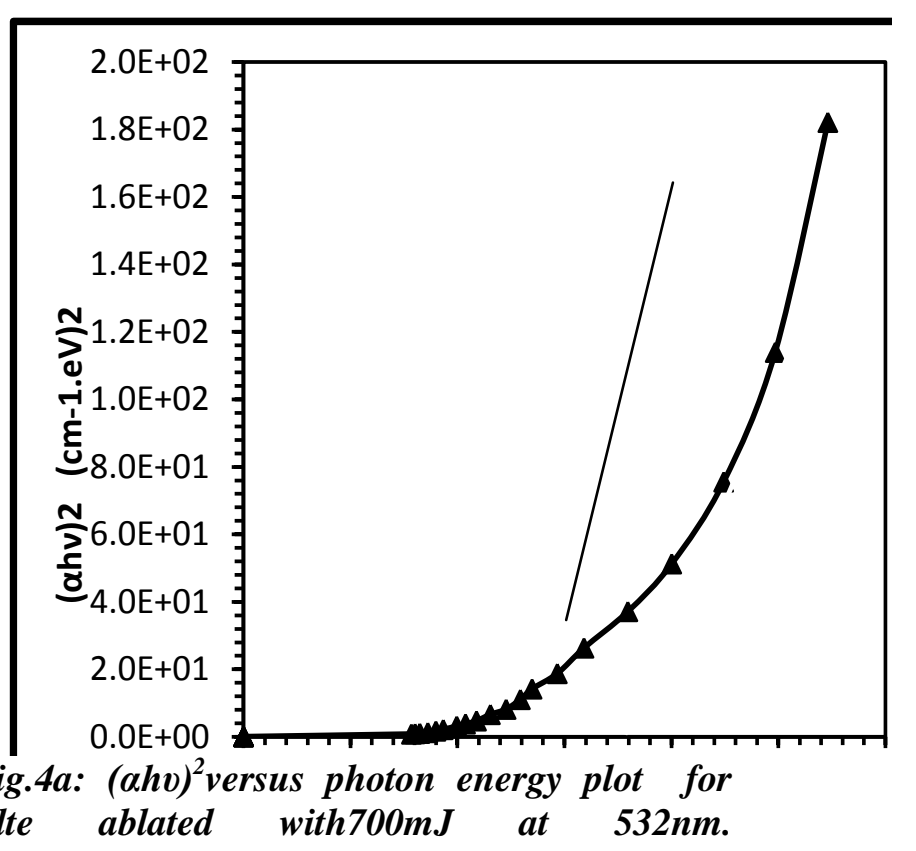




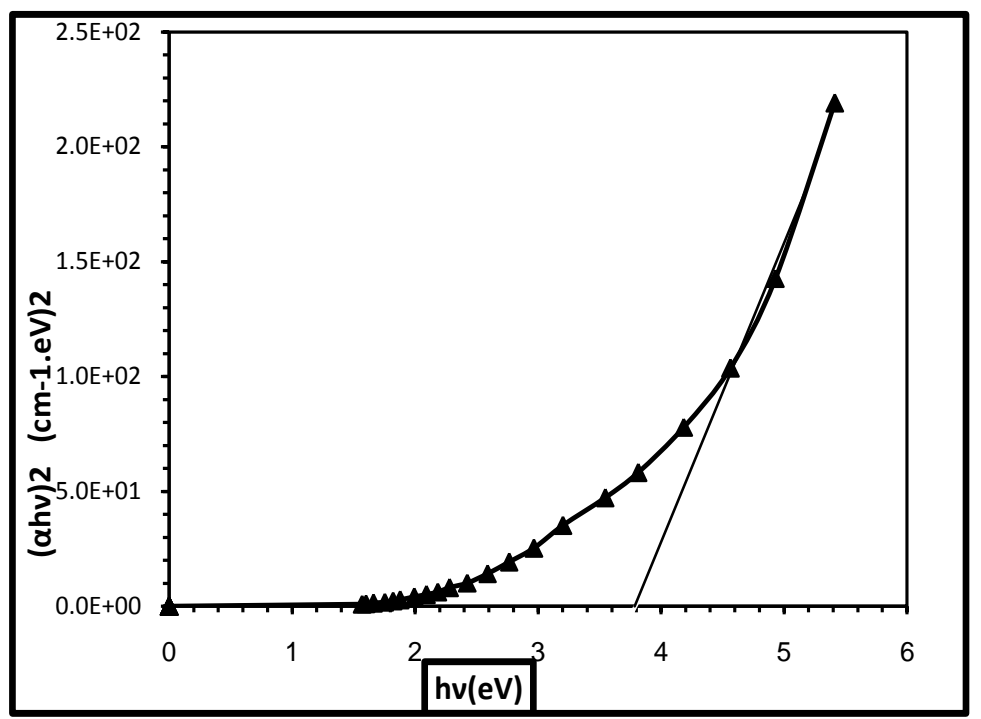

Fig.4b: (ahv) ${ }^{2}$ versus photon energy plot for CdTe ablated with700mj at 1064nm.

where $m^{*}=m_{e} \quad m_{h} /\left(m_{e}+m_{h}\right)$ is the electron-hole pair reduced mass considering the set of parameters $\mathrm{m}_{\mathrm{e}}=0.110, \mathrm{~m}_{\mathrm{h}}=\mathrm{m}_{\mathrm{hh}}=0.600$, and $\epsilon=10.6$, assuming electron (e) to heavy -hole (hh) transition which are the most probable, $\epsilon_{0}$ relative permittivity. The correction to be done on the bulk band gab energy is given by two terms. The first one is the confinement term that is proportional to $\mathrm{R}^{-2}$ and the second one stand for the coulomb interaction term that is usually negligible. The onset of absorption at $800 \mathrm{~nm}$ is consistent with absorption from an ensemble of NPs which have a maximum diameter of

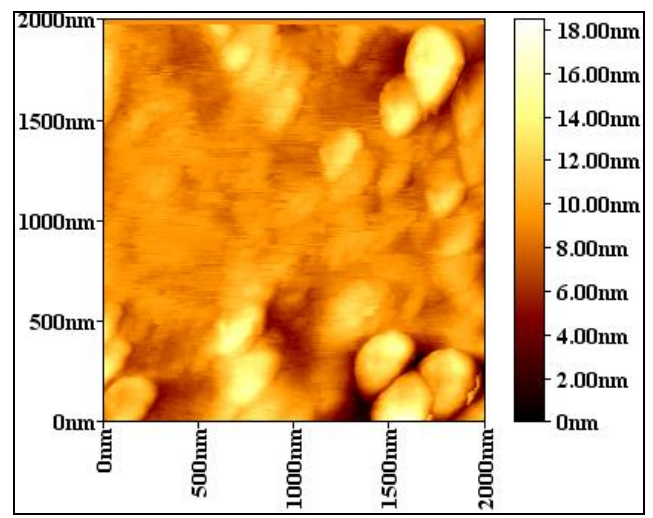

Fig. 5 a: AFM image of CdTe NPs.
$5 \mathrm{~nm}$ at laser wavelength $532 \mathrm{~nm}$ $(\mathrm{Eg}=4.18 \mathrm{eV})$ and a maximum diameter of $5.2 \mathrm{~nm}$ at $1064 \mathrm{~nm}(\mathrm{Eg}=3.95 \mathrm{eV})$ in Fig. 4b.

AFM image of the CdTe NPs produced in DDIW is shown in Fig. 5a the samples for AFM imaging have been prepared by drying the colloids on a clean glass substrate .That the NPs CdTe are spherical with size distribution centered at $47.23 \mathrm{~nm}$ for CdTe NPs prepared with $700 \mathrm{~mJ} \mathrm{Nd}: \mathrm{YAG}$ laser $(\lambda=1064 \mathrm{~nm})$ it is noticed from Fig. 5b the size distribution of CdTe NPs is nearly Gaussian type.

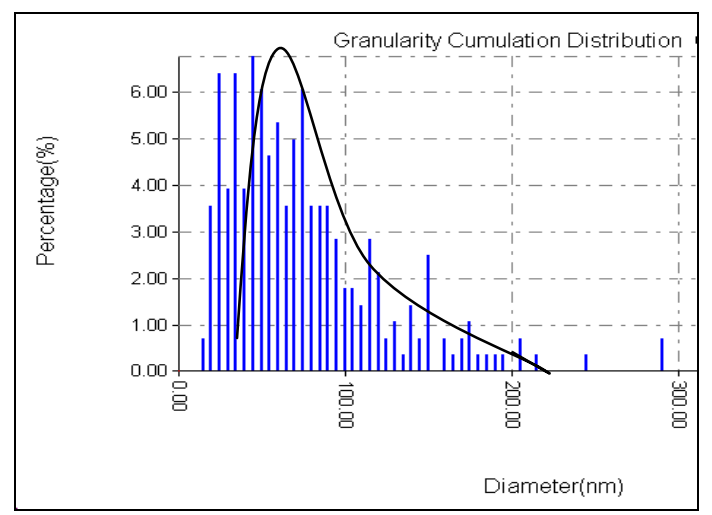

Fig. 5 b: Histogram of their size distribution in water. 


\section{Laser ablation in methanol}

Methanol has been applied as a solvent in comparison with water. During laser ablation in methanol, the color of the solvent has been changed to gray; we expect the formation of CdTe particles. The efficiency of particles formation is affected by properties of solution. Fig.6a indicates the UV-Vis absorption spectra from nanoparticles colloids of CdTe in methanol from laser energy $620 \mathrm{~mJ}$ and wavelength $1064 \mathrm{~nm}$. The spectra have

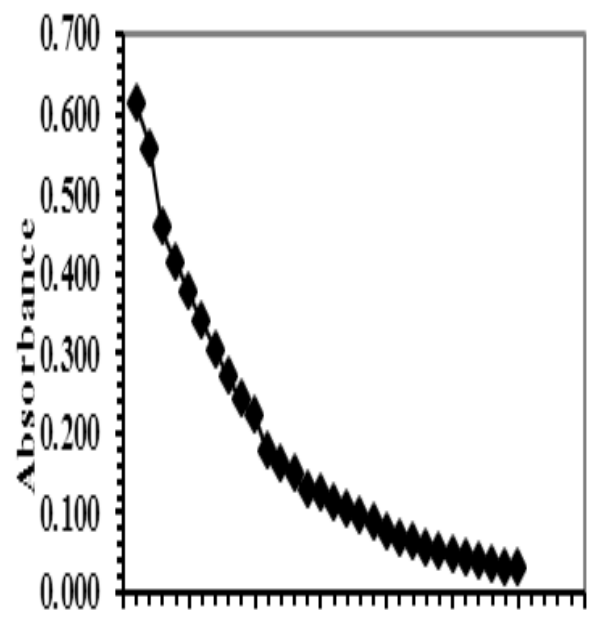

$300400500 \quad 6007008009001000$ Wavelength(nm)

Fig.6a: UV-Vis absorption spectra of nanoparticles colloid fabricated at wavelenght CdTe ablated with $620 \mathrm{~mJ}$ at $1064 \mathrm{~nm}$.

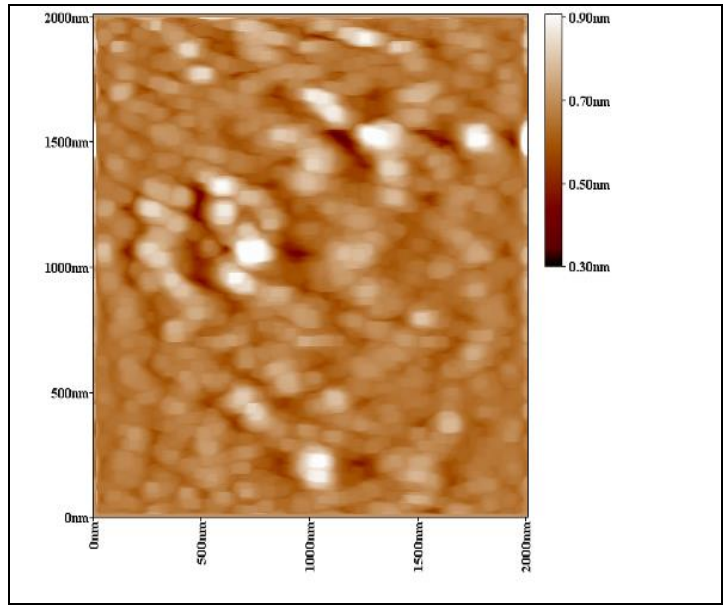

Fig. 7 a: AFM image of CdTe NPs. been measured with pure solution as references a voiding the signals from solution themselves. Fig.6b shows that the energy gab $\mathrm{Eg}=3.8 \mathrm{eV}$ with maximum diameter $6.33 \mathrm{~nm}$. AFM image Fig.7 of CdTe NPs produced in methanol, shows spherical shape with size distribution centered at $(87 \mathrm{~nm})$ for CdTe NPs prepared with $620 \mathrm{~mJ}$ Nd:YAG Laser wavelength 1064nm.

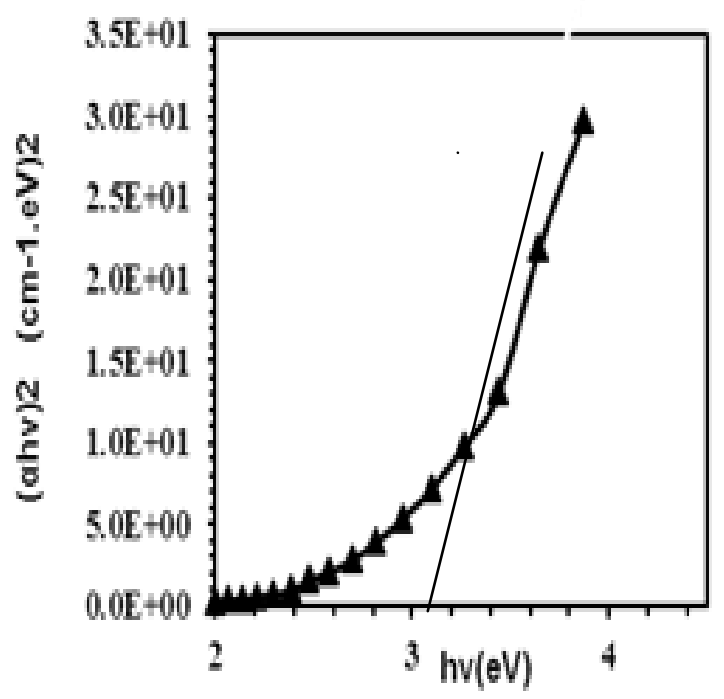

Fig.6b: $(\alpha h v)^{2} v e r s u s$ photon energy plot for laser of $1064 \mathrm{~nm}$ in methanol.

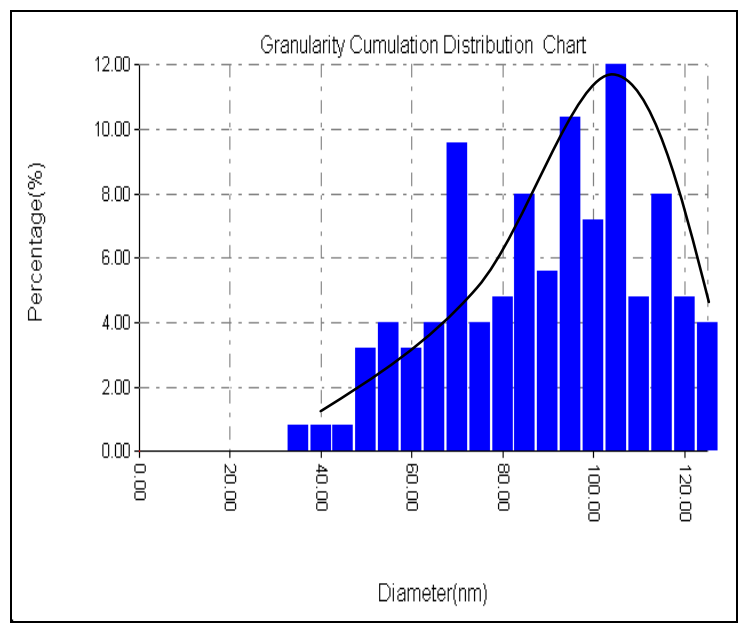

Fig. 7 b: Histogram of their size distribution. 


\section{Conclusions}

CdTe nanoparticles have been successfully fabricated by laser ablation at energy of $(620,700 \mathrm{mj})$, number of pulses 50 pulse and wavelength (532nm,1064nm) of CdTe target immersed in DDIW water and methanol .Through the (UV-VIS, AFM) it is found that the laser wavelength of $1064 \mathrm{~nm}$ is powerful than $532 \mathrm{~nm}$ to produce $\mathrm{CdTe}$ nanoparticles in water. The obtained nanoparticles are spherical in shape and homogenous. Laser ablation for fabricating CdTe nanoparticles in methanol shows that the absorbance spectra is increased continuously from 800 to $300 \mathrm{~nm}$. AFM images have shown spherical from of CdTe nanoparticles which are produced at both wavelengths at $620 \mathrm{~mJ}$.

\section{References}

[1] N.G.Semaltianos, S.Logothetidis, W.Perrie, S.Romani, R.J.Potter, Appl. Phys., A94 (2009) 641-647.

[2] A Albert. Ruth, John A. Young, Physicochem. Eng. Aspects, 279 (2006) 121-127.

[3] G.L.Tan, U.Hommerich, D.Temple, N.Q.Wu, J.G, Zheng, G.Loutts, Scripla Mater., 48 (2003) 1469-1474.

[4] A.Urbieta, P.Femandez, J.Piqueras, J. Appl. Phys., 96 (2004) 2210-2213.

[5] G.L.Tan, Q.Yang, U.Hommerich, J.T.Sec, D.Temple, Opt.Mater., 27 (2004) 579-584.

[6] A.Fojtik, A.Henglein, Ber.BunsenGes. Phys. Chem., 97(1993) 252-254.
[7] J.Neddersen, G.Chumanov, T.M. Cotton, Appl. Spectrose., 47 (1993) 1959-1964.

[8] Y.P.Lee, Y.H.Liu, C.S.Yeh, Phys. Chem., 1(1999) 4681-4686.

[9] S. R. J. Pearce, S. J. Henley, F. Claeyssens, P.W.May, K.R.Hallam, J.A.Smith, K.N.Rosser, Dimond Rel. Mater, 13(2004) 661-665.

[10] K. V. Anikin, N. N. Melnik, A. V. Simakin, G.A.Shafeev, V.V.Voronov, A.G.Vitukhnovsky, Chem. Phys. Lett., 366 (2002) 357-360.

[11] E.Jackson, R.AgeJr, A.Steigerwald, A.Ueada, D.Coffey, L.Al-Lard, Z.Pan, W.E.Collins, R.Mu, Phys. Status Solidi, C3 (2006) 3582.

[12] D.H.Lowndes, C.M.Rouleau, T. G. Thundat, G. Duscher, E. A. Kenik, S. J. Pennycook, J. Mater. Res.,14(1999) 359. [13] T. Koyama, S.Ohtsuka , H.Nagata, S.Tanaka, J. Cryst. Growth, 117(1992) 156.

[14] A.A.Ruth, J.A.Young, Colloids surf. A Physicochem, Eng. Asp., 279 (2006) 121.

[15] N.G.Semaltianos, S.Logothetidis, W. Perrier, S. Romani, R. J. Potter, M. Sharp, G. Dearden and K.G.Watkins, Applied Physics Letters, 95 (2009) 033302.

[16] Raid A.Ismail, Abdulrahman K. Ali, Mukhlis M.Ismail, KhaleelI. Hassoon, Appl. Nanosci, 1 (2011) 4549.

[17]A. Said, L. Sajti, S. Giorgio and W Marine, Journal of Physics, 59 (2007) 259-265. 